\title{
CORPORA SANCTORUM IN PACE SEPULTA SUNT, ET NOMINA EORUM VIVENT IN AETERNUM Peregrinatio christiana do Rzymu w czasach Grzegorza Wielkiego
}

Zagadnienia związane $\mathrm{z}$ tytułową peregrinatio christiana do Rzymu u schyłku starożytności chrześcijańskiej na przełomie VI i VII stulecia, a więc w czasach Grzegorza Wielkiego, rozpatrzę w dwóch aspektach. W części pierwszej artykułu zajmę się infrastrukturą miejską w tym czasie i wskażę miejsca, które ułatwiały przybyłym ad loca sancta „, funkcjonowanie” jako pątnikom w Wiecznym Mieście ${ }^{1}$. Skupię się przede wszystkim na ksenodochiach, a więc schroniskach i noclegowniach wybudowanych specjalnie z myślą o ludziach odbywających peregrynację do Rzymu. W drugiej zaś części wskażę motywy odbywania tego rodzaju peregrynacji i konkretne osoby, znane często z imienia dzięki zachowanym źródłom.

Już od czwartego stulecia na drogach całej chrześcijańskiej Europy zaczęły pojawiać się grupy ludzi zdążających ad loca sancta. Zrodziła się wówczas potrzeba budowania schronisk dla podróżnych i pielgrzymów - ksenodochiów, mających zapewnić nie tylko - oczywiście w miarę możliwości darmowy nocleg oraz doraźną opiekę: jedzenie, nowe ubranie, ale również podstawową opiekę lekarską ${ }^{2}$ i posługę religijną. Temu celowi nie mogły służyć przecież zwykłe tawerny, o których powszechnie było wiadomo, iż

\footnotetext{
${ }^{1}$ Por. m.in. I. Milewski, Rozwój chrześcijańskich instytucji dobroczynnych w Zachodniej części Cesarstwa Rzymskiego w IVi Vw., PrzRel 182 (1996) nr 4, 3-15; M. Wójcik, Instytucje dobroczynne w ,Listach” Grzegorza Wielkiego, VoxP 21 (2001) t. 40-41, 337-351; taż, Świeccy fundatorzy instytucji dobroczynnych w Kościele starożytnym, VoxP 22 (2002) t. 42-43, 327-351; B. IwaszkiewiczWronikowska, Świeccy jako fundatorzy kościelnych budowli w Rzymie wczesnochrześcijańskim, VoxP 22 (2002) t. 42-43, 339-337.

${ }^{2}$ Ksenodochia budowane wzdłuż uczęszczanych szlaków pątniczych, niekiedy pełniły też funkcję szpitali: świadczyły przybyłym pomoc medyczną, por. Wójcik, Instytucje dobroczynne, s. 343. Można przypuszczać, iż niektóre z nich - zwłaszcza te, które powstały w mniejszych miejscowościach lub na wsiach, gdzie nie było potrzeby tworzenia kilku wyspecjalizowanych instytucji - pełniły funkcje jak najbardziej ogólne, zob. E. Wipszycka, Les ressources et les activités économiques des églises en Égypte du IV au VIII siècle, Bruxelles 1972, 115.
} 
uchodzą za nieodpowiednie miejsca dla chrześcijanina, zwłaszcza pątnika ${ }^{3}$. Korespondencja Grzegorza z Nyssy, dosadnie obrazuje pokusy, jakie czyhały na pątników w czasie ich wędrówki. Choć interesujący fragment odnosi się konkretnie do mnichów wschodnich udających się do Ziemi Świętej, możemy przypuszczać, iż z podobnymi problemami spotykano się także w Europie Zachodniej ${ }^{4}$. Dodatkowo synod w Laodycei z 375 r. wydał zakaz korzystania przez chrześcijan z usług prywatnych tawern ${ }^{5}$.

Sama instytucja ksenodochiów ${ }^{6}$ na Zachodzie wywodzi się - jak powszechnie wiadomo - z tradycji wschodniej ${ }^{7}$. Nakazana przez Chrystusa gościnność - (hospitalitas) i niesienie pomocy bliźniemu stała się w starożytnym Kościele jedną z najważniejszych cnót chrześcijańskich oraz niewątpliwie stanęła u podstaw udogodnienia pątnikom ich wędrówki do miejsc kultu. Niewielkie domy biskupie, zwłaszcza od V wieku, z uwagi na coraz większą

${ }^{3}$ Por. J. Korpanty, Hotele, restauracje i szynki w starożytnym Rzymie, „Filomata” 182 (1964) 131-132; J. Wielowieyski, Na drogach i szlakach Rzymian, Warszawa 1984, 241-242.

${ }^{4}$ Por. Epistula 2 (De iis qui adeunt Jerosolyma), PG 46, 1012BC, thum. T. Sinko: Grzegorz z Nyssy, Wybór pism, Warszawa 1963, 226-227: „Ponieważ na Wschodzie zajazdy i gospody miasta nastręczają wiele swobody i obojętności wobec złego, jak może ten, kto przechodzi przez dym, nie mieć podrażnionych oczu? Gdzie brudzi się także serce, przyjmując przez wzrok i słuch bezeceństwa. Jakże więc będzie można przejść bez poruszenia namiętności przez miejsca dotknięte namiętnością?"; zob. też E. Jastrzębowska, Pielgrzymie dewocjonalia. Grzegorz z Nyssy przeciw pielgrzymom, MW 36 (1993) nr 10, 13-17; B. Kőtting, Gregor von Nyssa’s Wallfahrtskritik, StPatr 5 (1962) 360-367.

${ }^{5}$ Por. Concilium Laodicenum can. 24, Hefele-Leclercq I/2 1012-1013.

${ }^{6}$ Por. S. Longosz, Ksenodochium - hospicjum wczesnochrześcijańskie, VoxP 16 (1996) z. 3031, 275-336 (obszerna bibliografia); zob. też zebraną bibliografię: S. Longosz, Charytatywna działalność starożytnych chrześcijan. Materiały bibliograficzne, VoxP 16 (1996) z. 30-31, 493-510; także: J.M. Besse, L'hospitalité monastique dans les solitudes orientales, w: Les moines d'Orient, Paris 1900, 474-483; J. Imbert, Les hopitaux en droit canonique, Paris 1947; H. Leclercq, Hôpitaux, hospices, hotelleries, DACL VI 2, 2762-2765; C.C. Paolucci, L'attività ospitaliera nell' antico monachesimo. Note su alcune testimonianze delle più antiche fonti monastiche, „Studi e Ricerche sull'Oriente Cristiano" 6 (1986) 173-180; B. Pawłowska, Urbs Sacra. Pielgrzymki i podróże religijne do Rzymu w starożytności chrześcijańskiej (IV-VII w.), Kraków 2007, 215-245; R. Santangeli Valenzani, Pellegrini, senatori e papi. Gli xenodochia a Roma tra il IX secolo, „Rivista dell'Istituto Nazionale d'Archeologia” 19-20 (1996-1997) 203-226; H.G. Severin, Pilgerwesen und Herbergen, w: Akten des XII. International Kongresses für Christliche Archäologie (Bonn, 22-28 September 1991), I-II, Münster 1995, 329-330; F.R. Stasolla, Gli xenodochia, w: Christiana loca. Lo spazio cristiano nella Roma del primo millennio,ed. L. Pani Ermini, t. 1, Roma 2000, 189-191.

${ }^{7}$ Przemawiają za tym wyraźnie odnajdywane w źródłach, chociażby greckie, jedynie zlatynizowane nazwy tych instytucji: xenodochium lub ich formy oboczne: scenodochium, senodochium, synodochium i in. Rzecz ciekawa, że starożytni chrześcijanie dość rzadko używali na oznaczenie swoich zakładów dobroczynnych terminów łacińskich: hospitia, ospitium, hospitale, domus hospitalis, choć funkcjonowały one już u autorów przedchrześcijańskich m.in. na oznaczenie kwatery gościnnej lub zajazdu, por. O. Hiltbrunner, s.v. Xenodochium, RE IX 1489-1490; Milewski, Rozwój chrześcijańskich instytucji dobroczynnych, s. 4; Stasolla, Gli xenodochia, I, s. 187-199, a także II (Roma 2001), s. 156-157. 
liczbę pątników ad loca sacra, nie mogły już ich wszystkich pomieścić. Do tego należałoby dodać wzrastającą liczbę klasztorów, których reguły również zalecały opiekę nad pielgrzymami, ubogimi i bezdomnymi ${ }^{8}$. Jeśli przybysz był chory, zapewniano mu leczenie; jeśli miał zniszczone ubranie, dawano mu nowe; jeśli był ubogi, ofiarowywano mu często drobne pieniądze, sprawdzając jednak uprzednio, czy nie jest oszustem i nie pojawił się w schronisku celem łatwego zdobycia pieniędzy ${ }^{9}$. Na pierwszym miejscu stawiano więc - jak widać - przede wszystkim zaspokojenie potrzeb duchowych, dając pielgrzymom mnóstwo okazji do medytacji i modlitw. Wydaje się, iż nie było formalnego cennika wskazującego, jaką opłatę każdy z odwiedzających miałby wnieść za otrzymany "pokarm fizyczny i duchowy". Możemy się jednak domyślać, że istniał zwyczaj pozostawiania przez tych, którzy sobie mogli na to pozwolić, datków różnej wysokości.

W czasach Grzegorza Wielkiego ${ }^{10}$, jak wynika z jego korespondencji, w miarę prężnie działały w Wiecznym Mieście co najmniej cztery instytucje dobroczynne, z usług których mogli korzystać przybywający pątnicy. Można jednak przypuszczać, że inne, zakładane wcześniej, biorąc pod uwagę chociażby ich usytuowanie, również funkcjonowały ${ }^{11}$. I tak w liście Grzegorza z 591 r.

${ }^{8}$ Por. Regula S. Benedicti 53, 1, SCh 182, 610-612 (De hospitibus suscipiendis): „Omnes supervenientes hospites tamquam Christus suscipiantur, quia ipse dicturus est: «Hospis fui et suscepistis me», et omnibus congruus honor exhibeatur, maxime domesticis fidei et peregrinis"; tamże 61, 1-3, SCh 182, 636-638 (De monachis peregrinis, qualiter suscipiantur): „Si quis monachus peregrinus de longinquis provinciis supervenerit, si pro hospite voluerit habitare in monasterio et contentus est consuetudinem loci quam invenerit, et non forte superfluitate sua perturbat monasterium, sed simpliciter contentus est quod invenerit, suscipiatur quanto tempore cupit".

${ }^{9}$ Por. L. Casson, Podróże w starożytnym świecie, thum. A. Flasińska - M. Radlińska-Kardaś, Wrocław 1981, 231; D. Gorce, Les voyages, l'hospitalité et le port des lettres dans le monde chrétien des IV et V siécles, Paris 1925, 178-184; Longosz, Ksenodochia, s. 330.

${ }^{10}$ Biografię Grzegorza Wielkiego odnajdziemy m.in. w: M. Banniard, Geneza kultury europejskiej V-VIII wieku, thum. A. Kuryś, Warszawa 1995, 133-137; J. Czuj, Papież Grzegorz Wielki, Warszawa 1948; T. Wolińska, Stosunki papieża Grzegorza Wielkiego z dworem cesarskim i administracja bizantyjska, Łódź 1998; R.A. Markus, Grzegorz Wielki, tłum. P. Nehring, Łódź 2003.

${ }^{11}$ Chodzi mianowicie o tzw. xenodochium Pammachii założone w latach dziewięćdziesiątych IV w. przez rzymskiego senatora Pammachiusza w rzymskim morskim porcie Ostii (usytuowanie oraz szczegóły jego funkcjonowania por. m.in.: S. Coccia, Il „Portus Romae” tra tarda antichità e altomedioevo, w: P. Delodu, La storia economica di Roma nell'alto Medioevo alla luce dei recenti scavi archeologici, Firenze 1993, 177-200; P.A. Février, Ostie et Portus à la fin l'antiquitè, „Mélanges d'Archéologie et d'Histoire” 70 (1958) 295-330; Longosz, Ksenodochium., s. 309-310 i 332-333; Rajna, Strade, pellegrinaggi, s. 13; G.B. De Rossi, I monumenti cristiani di Porto, BAC 4 (1866) 37-51; tenże, Dello xenodochio di Pammachio, BAC 24 (1886) 50-51; „Roman Ostia” revisited. Archeological and historical papers in memory of R. Meiggs, ed. A. G. Zevi-A. Claridge, London 1996, 267-307 i inne). W biografii Symmacha (498-514), zawartej w Liber Pontificalis (ed. L. Duchesne, I-III, Paris 1955, I 263), odnajdujemy zapis, że on: „Item ad beatum Petrum et ad beatum Paulum et ad sanctum Laurentium pauperibus habitacula construxit". Pojawia się tu termin pauperibus habitacula, co dosłownie oznacza: ,pomieszczenie, dom dla biednych, osłabionych, 
skierowanym do subdiakona Piotra, administratora dóbr Kościoła rzymskiego na Sycylii, czytamy:

\author{
„Przyślij nam wpłaty gospody (xenodochii) przy Nowej Drodze, które - jak \\ piszesz - masz u siebie"12.
}

Położenie tego ksenodochium lokalizuje się przy Via Nova w pobliżu kościoła śś. Nereusza i Achillesa ${ }^{13}$ (dawny titulus Foscialae ${ }^{14}$ ), niedaleko kom-

opadających z sił" (por. Ae. Forcellini, Lexicon Totius Latinitatis, I, Patavia 1940, 631 lub ed. Prati 1865, III, 255: s.v. habitaculum - „locus, in quo quis habitat”). W ramach dobroczynności chrześcijańskiej rozciągano m.in. opiekę nad ludźmi potrzebującymi wsparcia. Być może i z ich usług mogli korzystać pątnicy. Na Zachodzie bowiem w IV i w V stuleciu nie wykształcił się jeszcze w pełni zakres funkcji pełnionych przez poszczególne instytucje charytatywne, jak to miało miejsce w tradycji wschodniej Wymienione w tym ostatnim źródle schroniska zostały wybudowane przecież przy trzech głównych rzymskich bazylikach: św. Piotra na Watykanie, św. Pawła przy Drodze Ostyjskiej oraz św. Wawrzyńca na Campo Verano przy Drodze Tyburtyńskiej. Były to przecież w tym okresie - jak chociażby poświadcza poeta Prudencjusz w Peristephanon (XII [Piotr i Paweł], CCL 126, 379 381, PSP 43, 289-290; II [Wawrzyniec], CCL 126, 257-277, PSP 43, 210-229), miejsca kultu nawiedzane thumnie nie tylko przez mieszkańców - pątników z samego Rzymu i z okolicznych stron, ale również z odleglejszych krain. Pojawienie się za pontyfikatu Symmacha przy trzech głównych rzymskich bazylikach przytułków potwierdzają również źródła aż do XII wieku, w których czytamy w prawie niezmienionej formie zdanie: „Symmachus papa [...] ad beatum Petrum, et beatum Paulum apostolos, et ad sanctum Laurentium martyrem pauperibus habitacula construxit" (szczegóły zob. B. Pawłowska, Urbs Sacra, s. 220-227. Źródła z VI wieku, zwłaszcza Liber Pontificalis (= LibPont), wskazują na funkcjonowanie kolejnego ksenodochium za papieża Wigiliusza (537-555) przy Via Lata: „Fecit enim Vilisarius patricius xenodochium in via Lata; et in via Flaminea iuxta civitate Mortas monasterium sancti Iuvenalis, ubi possesiones et dona multa largius est" (I 296) i za papieża Leona III (795-816): „Enim vero et in oratorium sanctae Dei genetricis, sito in senodochio Firmis fecit vestem de stauraci pulcherrima" (II 12). Wymienione tu oratorium Świętej Bożej Rodzicielki to późniejsze oratorium s. Mariae (II 46, n. 108: xen. Firminis - orat. S. Mariae), które w średniowieczu zostało przebudowane na kościół S. Maria in xenodochio (por. ICVR II 445, 186: „Supra Ianuam templi S. Mariae de Trivio quae dicitur in Xenodochio: HANC VIR PATRICIUS VILISARIUS URBIS AMICUS"; zob. też: C. Bertelli - G. Paluzzi, S. Maria in via Lata, Roma 1971; C. Cecchelli, S. Maria in Via, Roma 1925, 14-16; L. Cavazzi, S. Maria in via Lata e gli odierni scavi nel suo antico oratorio, „Miscellanea di storia e cultura ecclesiastica” 3:1904-1905, 193-203). $\mathrm{Z}$ materiału źródłowego wynika, że w poł. VI wieku przy Via Lata funkcjonowała prywatna fundacja - xenodochium Vilisarii, która albo upadła, a na jej miejscu pojawiła się i na przełomie VIII i IX w. prowadziła swą działalność, pod zmienioną nazwą senodochium Firminis, albo też funkcjonowała przez cały czas (zmieniając tylko nazwę) i przetrwała aż do czasów średniowiecza, gdy na jej miejscu wybudowano kościół.

${ }^{12}$ Gregorius, Epistula I 42, CCL 140, 55-56: „Pensiones xenodochii de via-nova, quantas mihi indicasti, quia apud te habes, nobis dirigere", thum. Czuj I 79.

${ }^{13}$ Por. R. Krautheimer, Corpus Basilicarum Christianarum Romae, III, Città del Vaticano 1967, 135-152.

${ }^{14}$ Titulus Fasciolae wymieniony jest w aktach synodu rzymskiego z 499 r., por. F. Guidobaldi, L'inserimento delle chiese titolari di Roma nel tessuto urbano preesistente: osservazioni ed implicazioni, w: Quaeritur inventus colitur. Miscellanea in onore di Padre U.M. Fasola, Cittá del Vaticano 1989, 386-391; L. Pani Ermini, Roma tra fine del IV e gli inizi del V secolo, w: Milano capitale dell' 
pleksu term Karakalli ${ }^{15}$. Nie ma niestety innych, bardziej szczegółowych wzmianek, dzięki którym moglibyśmy bardziej precyzyjnie określić czas powstania tego ksenodochium; jedno wiemy na pewno - funkcjonowało ono i prowadziło swą działalność dobroczynną już w 591 r., a kierował nim wówczas - jak poświadcza cytowany wcześniej list - diakon Florencjusz.

Kolejną instytucją dobroczynną, wymienioną przez Grzegorza Wielkiego, jest xenodochium Anichiorum:

„A my na prośbę najmilszego syna naszego diakona Florencjusza, obiecaliśmy dziesięć klaczy z ogierem przytulisku (xenodochio) Anicjów - gdzie jak wiadomo - jest on przełożonym"16.

Musiała ona rzeczywiście dobrze prosperować, skoro wzmiankę o niej odnajdziemy również w źródłach późniejszych, m.in. w biografii papieża Leona III (795-816). To właśnie dzięki niej możemy pokusić się o bliższe sprecyzowanie miejsca położenia tego ksenodochium:

„oratorium sanctae Luciae in xenodochio qui dicitur Anichiorum" ${ }^{17}$.

Jak się wydaje, zostało ono ufundowane przez gens Anicia. Dwie osoby możemy zidentyfikować jako ewentualnych jego założycieli: Anicius Acilius Glabrio Faustus - konsul w 438 i prefekt Rzymu w latach $408-437^{18}$ albo Anicius Acilius Aginantus Faustus - konsul w 483 oraz prefekt Rzymu w latach 475-482 i 502-503 ${ }^{19}$. Tę kwestię, według Riccardo Santangeli Valenzani ${ }^{20}$, rozwiązuje odnaleziony i odczytany przez M. Guarducci ${ }^{21}$ fragment inskryp-

imperio romano. Felix temporis reparatio. Atti del convegno archeologico internazionale (Milano, 8-11 III 1990), Milano 1992, 195-196.

${ }^{15}$ Por. M.G. Cecchini, Terme di Caracalla, sepolcreto altomedievale, RivAC 63 (1987) 380381; Krautheimer, Corpus Basilicarum, III, s. 135-152; Santangeli Valenzano, Pellegrini, senatori e papi, s. 212-213; R. Santangeli Valenzano - R. Volpe, Nova via, „Bullettino della Commissione Archeologica. Comunale di Roma" 93 (1989-1990) 23-30.

${ }^{16}$ Epistula IX 8, CCL 140A, 570: „Filio nostro Florentino diacono, xenodochio Anichiorum, cui praesse dignoscitur", Czuj III 61-62; por. też: s.v. Xenodochium Aniciorum, Lexicon Topographicum Urbis Romae, ed. E.M. Steinby, Roma 1999, 215-216.

${ }^{17}$ LibPont II 25.

${ }^{18}$ Por. odnaleziony fragment inskrypcji wykutej ad circum Flaminium: ,DD * NN * AETERNIS * PRINCIPIBUS * HONORI * (et Theodosio augusto) / ANICIUS * ANCILIUS * GLABRIO * FAUSTUS $*$ VC $*$ PRAEF $*$ VR(bi) $/$ FATALI $*$ CASV $*$ SVBVERSAM $*$ IN $*$ FORMAM $*$ PRISCI * VSVS", CIL VI 1676.

${ }^{19}$ Por. J.R. Martindale, The Prosopography of the Later Roman Empire, II, Cambridge 1980, s. v. Faustus: Anicius Acilius Glabrio Faustus 8, 452-454; Anicius Acilius Aginantus Faustus 4, 451-452.

${ }^{20}$ Por. Santangeli Valenzano, Pellegrini, senatori e papi, s. 205-207.

${ }^{21}$ Por. M. Guarducci, Intorno all' epigramma greco del basso Impero concernente il santuario di Bellone e il Circo Flamino, „Rivista di Filologia e d'Istruzione Classica” 82 (1954) 383-397; taż, L'epigrafia di Fausto e le nuove scoperte in Campo Marzio, „Atti della Pontificia Accademia Romana di Archeologia. Rendiconti” 42 (1969/1970) 219-243. 
cji: FAVSTVS XENODOCHOS ${ }^{22}$, wskazujący, iż fundatorem ksenodochium był Glabrion Faustus. Możemy przyjąć bardzo ogólnie, że czas jego powstania przypada na $\mathrm{V}$ wiek.

Za czasów Grzegorza Wielkiego funkcjonowało również ksenodochium Waleriusza, ufundowane również w V wieku przez gens Valeria. Z korespondencji papieskiej dowiadujemy się, że kierował nim wówczas subdiakon Antoniusz. Grzegorz wspomina też spory toczone między opatem klasztoru śś. Maksyma i Agaty w Panormos, a administratorami ksenodochium o posiadłości na terenie panormitańskim ${ }^{23}$. W ślad za G. B. De Rossim domus familiarum Valeriis lokalizuje się na Monte Caelio ${ }^{24}$ przy kościele św. Szczepana. Ksenodochium to funkcjonowało przez długi okres czasu, bowiem wzmiankę o nim odnajdujemy również w biografii papieża Stefana III (768-772):

„Dirigentes illum in xenodochio Valerii, ibidem postmodum ex eodem oculorum effoditione vitam finit"25.

I wreszcie czwarta instytucja filantropijna, dwukrotnie wspominana przez Grzegorza Wielkiego - ksenodochium usytuowane przy wejściu do bazyliki św. Piotra. W liście datowanym na 598 r. czytamy:

„Nam poważnie zależy na uporządkowaniu rachunków zmarłego skarbnika Bonifacjusza, dlatego, iż jakąś część swego majątku zapisał domowi zajezdnemu (xenodochia) położonemu przy kościele błogosławionego Piotra, Księcia Apostołów"26.

Źródła nie pozwalają jednoznacznie stwierdzić, czy owo ksenodochium funkcjonujące w czasach Grzegorza Wielkiego jest kontynuacją pauperibus habitaculum ad beatum Petrum, założonego przez papieża Symmacha (498$514)^{27}$, czy też chodzi tutaj o jakąś zupełnie nową fundację, powstałą czy to na gruzach poprzedniej, czy też funkcjonującą zupełnie niezależnie. Brak jest

${ }^{22}$ Por. Inscriptiones Graecae Urbis Romae, ed. L. Moretti, I, Roma 1968, 69, 62.

${ }^{23}$ Por. Epistula IX 66a, CCL 140A, 623, Czuj III 61-62: „Długo ciągnął się spór [...] między zarządcami domu zajezdnego w tutejszym mieście Rzymie, który to dom nazywa się domem (xenodochii) Waleriusza, teraz zaś doszło za sprawą do zbawiennego porozumienia między tobą, najmilszym synem naszym Domicjuszem, opatem i kapłanem rzeczonego klasztoru, a subdiakonem naszym Antoniuszem, przełożonym wspomnianego domu zajezdnego (xenodochium)"; podobną treść odnajdziemy w Epistula IX 82 (ad Antonium), CCL 140A, 637, Czuj III 122.

${ }^{24}$ Por. G.B. de Rossi, La casa dei Valeri sul Celio e il Monastero di S. Erasmo, „Studi e documenti di Storia e Diritto" 1886, 235-243; na podstawie zachowanej wzmianki w Żywocie świętej Melanii (zob. Vita sanctae Melaniae iunioris auctore coevo et sanctae familiari, AnBol 8:1889, 16-63).

${ }^{25}$ LibPont I 473.

${ }^{26}$ Epistula IX 131, CCL 140A, 681, Czuj III 161-162; zob. inną wzmiankę dotyczącą tej samej sprawy: Epistula IX 63, CCL 140A, 619-620, Czuj II 106: „Zmarły rachmistrz Bonifacjusz zapisał w testamencie jakąś część swego spadku na rzecz domu zajezdnego (xenodochium) położonego obok św. Piotra, Księcia Apostołów”.

${ }^{27}$ Por. wyżej noty 11 i 14. 
pośrednich źródeł, które mogłyby przechylić szalę na którąkolwiek ze stron. Późniejsze źródła wyraźnie wskazują, że w czasach papieża Hadriana I (772795) ksenodochium położone przy bazylice watykańskiej funkcjonowało już jako hospitale lub xenodochium $S$. Gregorii ${ }^{28}$. W żadnym z listów Grzegorza Wielkiego nie ma wzmianki o tym, iż to on był założycielem jakiegokolwiek ksenodochium, w jego biografii zawartej w Liber Pontificalis również nie odnajdujemy podobnej myśli. Być może trzeba brać w tym wypadku pod uwagę tradycję, która przypisała właśnie jemu założenie tej fundacji. Jak musiała być ona silna, świadczyć może choćby inskrypcja z bazyliki watykańskiej, pochodząca z XII wieku i opisana przez Pietro Mallio. Czytamy w niej, że to właśnie Grzegorz Wielki:

„Fecit sinodochium sancti Gregorii iuxta gradus Beati Petri et constituit ibi tres cantores cum primicerio" 29.

Rzymskie instytucje dobroczynne usytuowane były tak, by ułatwić pobyt, choćby ze względów stricte praktycznych i organizacyjnych, ludziom nawiedzającym loca sancta w Wiecznym Mieście. Wyjątkiem będzie tu hospicjum ostyjskie - położone w pobliżu portu ${ }^{30}$; jak łatwo się można domyślić, właśnie z uwagi na takie, a nie inne jego położenie, korzystali z niego nie tylko peregrini udający się do samego Rzymu ${ }^{31}$. Pozostałe znajdowały się w pobliżu miejsc kultu: bazylik lub grobów męczenników, nawiedzanych licznie przez pątników. Miało to na celu ułatwić przybyłym uczestnictwo w obrzędach i uroczystościach (niekiedy przybysze z okien mogli słuchać śpiewów liturgicznych) $)^{32}$. W pobliżu rzymskich loca sancta powstawało coś na kształt dzielnic pątniczych. W trosce o zapewnienie regularnej służby godnej męczennika, biskupi rzymscy od $\mathrm{V}$ stulecia zakładali również klasztory ${ }^{33}$ przy znaczniejszych bazylikach. To tam mnisi odśpiewywali wigilie i odprawiali liturgie. Majątki, jakie klasztory otrzymywały od fundatorów i na mocy testamentów, umożliwiały działalność na polach kultury, życia religijnego i społecznego, w tym i nad wszelkimi przejawami ruchu peregrynacyjnego.

${ }^{28}$ LibPont I 506: „Et alia diaconia quae appellatur sancti Silvestri, quae ponitur iuxta hospitale S. Gregorii".

${ }^{29}$ Por. P. Mallio, Opusculum historiae sacrae de sacratissima basilica s. Pietri in Vaticano, w: R. Valentini - G. Zucchetti, Codice topografico fella città di Roma, II, Roma 1942 (repr. 1960) 404.

${ }^{30}$ Por. wyżej notę 11.

${ }^{31}$ Stanowiło ono jeden z etapów podróży dla pielgrzymów i podróżnych przybywających m.in. z Afryki Północnej do Rzymu, ale ksenodochium to było również jednym z miejsc, w którym znajdowali nocleg i opiekę również pątnicy, udający się na pielgrzymkę do Ziemi Świętej.

${ }^{32}$ Por. Gorce, Les voyages, s. 192-193.

${ }^{33} \mathrm{Na}$ temat najstarszych rzymskich klasztorów zob. przede wszystkim: G. Ferrari, Early Roman monasteries. Notes for the history of the monasteries and convents at Rome from the V through the X century, Città del Vaticano 1957; a także bibliografię zebraną w: Pawłowska, Urbs Sacra, s. 246, nota 903 . 
Stawiano tu również i inne instytucje przeznaczone dla wszechstronnej opieki nad pątnikami - baptysteria ${ }^{34}$ oraz balnea ${ }^{35}$. W ten sposób powstało niejako „zaplecze” służące przybyłym do miejsc kultu: gwarantowało przybyszom pewne wygody, duszpasterzom zaś ułatwiało katechezę i „nadzór” nad pątnikami. Można stwierdzić, iż budowa ksenodochiów, przeznaczonych dla ludzi odbywających peregrynację stanowiła „punkt honoru” dla wielu biskupów i dostojników świeckich, chociażby dlatego, iż było widomym znakiem realizacji nakazanych przez Chrystusa chrześcijańskich cnót: gościnności (hospitalitas) i służebności bliźniemu ${ }^{36}$.

$\mathrm{Na}$ ksenodochów, czyli zarządców interesujących nas instytucji dobroczynnych, wybierane były najczęściej osoby cieszące się nieskazitelną opinią, samotne lub przestrzegające zasad ubóstwa. Jeden z kanonów arabskich ( $c a-$ nones arabici) Soboru Nicejskiego (325 r.), nakazujący zakładanie ksenodochiów w każdym mieście biskupim, zalecał nawet, by biskupi wybierali na ich zarządcę któregoś z mnichów ${ }^{37}$, mieszkającego daleko od swej rodziny i spraw rodzinnych oraz cieszącego się nieposzlakowaną opiniąą ${ }^{38}$ Nieco później (594 r.) w podobnym duchu zalecenia wypowiadał się Grzegorz Wielki:

„Na kierownictwo w nich [ksenodochiach] należy wybierać takich mężów, którzy życiem, obyczajami i pracowitością byliby najgodniejsi, i tylko zakonników, aby sędziowie nie mieli możliwości dokuczania im"39.

Cytowany powyżej arabski kanon Soboru Nicejskiego jasno podkreślał, że ksenodoch ma być zarządcą i opiekunem podległej mu instytucji, troszczącym się o jej wszystkie potrzeby. Do jego obowiązków należało m.in. przygotowanie łóżek, pościeli i wszystkiego tego, co było niezbędne dla przebywających tam „braci, pielgrzymów, biednych i chorych" ${ }^{40}$. Gdy dobra kościelne nie wystarczały na utrzymanie fundacji, mieli oni za zadanie zbierać datki od wiernych, których wysokość uzależniano od ich zamożności ${ }^{41}$.

${ }^{34}$ Por. L. Reekmans, L'implantation monumental chrètienne dans la zone suburbaine de Rome du IV au IX siècle, RivAC 44 (1968) 173-207.

${ }^{35}$ Por. F.R. Stasolla, Balnea, w: Christiana loca I 200-202.

${ }^{36}$ Por. V. Monachino, La carità cristiana a Roma in antichità e l'alto Medioevo, w: La carità cristiana a Roma, ed. tenże, Bologna 1968, 1-168; H. Wójtowicz, Gościnność wczesnochrześcijańska, VoxP 16 (1996) z. 30-31, 229-239, spec. 231-238 (wczesnochrześcijańskie świadectwa o gościnności).

${ }^{37}$ Według prawa rzymskiego nie było wymogu, by zarządcą musiał być mnich, por. Wójcik, Instytucje dobroczynne, s. 343.

${ }^{38}$ Por. Concilii Nicaeni canones arabici can. 75, Mansi II 1006: „Et eligat episcopus virum aliquem ex monachis deserta habitantibus qui sit alienigena, et longinqua patria, atque a suis distans domesticis, quinque bonum habeat de se testimonium ac notae sit etiam probitatis et praeficiat eum domicilio"

${ }^{39}$ Epistula IV 24, CCL 140, 242, Czuj II 34.

${ }^{40}$ Por. Concilii Nicaeni canones arabici can. 75, Mansi II 1006: „fratres, peregrini, pauperes et aegroti”.

${ }^{41}$ Por. tamże: „Illiusque officii erit parare lectos, strata et omnia ea, quae aegrotis et pauperibus opus sunt. Quod si bona ecclesiae non sint, ut sufficere possint ad eiusmodi impensas, colligat eis 
W ściśle określonym czasie ksenodoch - jak jasno zaznacza Kodeks Justyniana - miał obowiązek oficjalnego rozliczania się ze swej działalności przed biskupem, w przypadku zaś śmierci, obowiązek ten przechodził na jego spadkobierców ${ }^{42}$. Podobne wskazówki odnajdziemy w korespondencji Grzegorza Wielkiego:

„Gospody (xenodochia) zgodnie z panującym zwyczajem składają dokładne rachunki przed biskupem miasta (apud episcopum civitatis), gdyż oczywiście biskupi winni się nimi opiekować i czuwać nad ich kierownictwem (sollicitudine gubernanda)... Napominamy, aby jak powiedziano, zarządcy, którzy są lub byli w tych domach, w oznaczonych terminach składali dokładne rachun$\mathrm{ki}$ (singulis quibusque temporibus rationes suas xenodochi [...] ponant)"43.

W innym liście Grzegorz pisze, że należałoby ostro skarcić Januariusza, biskupa Sardynii, za to, że dopuścił się tak wielkich zaniedbań w podległych mu ksenodochiach:

„Tylko wstrzymał nas od tego wzgląd na jego starość, prostoduszność i grożącą mu chorobę" ${ }^{\prime 4}$.

Ksenodochia chrześcijańskie były, jak się wydaje, udostępniane przede wszystkim dla „braci w wierze”45. Z czasem wypracowany został zwyczaj pisa-

per diaconos sumptus a fidelibus omni tempore, et accipiat a christianis per singulos secundum uniuscuiusque facultates et vires, et his sustententur fratres, peregrini, pauperes et aegroti, ut cuique opus est, siquidem ipse illorum procurator et provisor est ac proinde eorum necessitatibus pro viris consulere debet: in hoc quippe magna remittuntur peccata, delicta expiantur et maxime ad Deum acceditur"; zob. też: Joannes Chrysostomus, De sacerdotio III 16, PG 48, 656, thum. W. Kania, POK 23, 73: „A ileż jest wydatków pieniężnych, jakiej trzeba pilności i roztropności w przyjmowaniu podróżnych! [...]. Przełożony musi więc być w przyjmowaniu delikatny i roztropny, musi umieć skłonić bogatych do szczodrego i chętnego składania ofiar".

${ }^{42}$ Por. Codex Iustinianus I 3, 41, 9-10: „Post mortem vero religiosissimorum episcoporum pro tempore oeconomi debent rationes exigere rerum ab iis relictarum, quae ex hac lege nostra ad sacrosanctam magnam ecclesiam pertinere debent. Ipsos etiam oeconomos cum iudicio ac consideratione creari iubemus scientes omnimodo singulis annis rationes administrationis suae sanctissimo episcopo reddere".

${ }^{43}$ Epistula IV 24, CCL 140, 242, Czuj II 33-34.

${ }^{44}$ Epistula XIV 2, CCL 140A, 1066: „Unde reverentissimus frater et coepiscopus noster Ianuarius vehenentissime fuerat obiurgandus, nisi nos eius senectus ac simplicitas et superveniens aegritudo, quam ipse retulisti, suspenderet", Czuj IV 227.

${ }^{45}$ Od początku bowiem swego istnienia Kościół był bardzo ostrożny, by ze zbieranych datków nie wspierać oszustów i fałszywych gości; już najstarsze (koniec I w.) wczesnochrześcijańskie pismo Didaché zaleca (12, SCh 248, 188, tłum. A. Świderkówna, PSP 45, 63): „Przyjmujcie każdego, kto przychodzi w imię Pana. Później wypróbujcie go i poznajcie, potraficie bowiem odróżnić prawą rękę od lewej. Jeśli przybysz jest tylko przejazdem, pomóżcie mu, na ile was stać, a niech nie zostanie u was dłużej niż dwa lub trzy dni, gdy konieczne. Jeśli zaś chce u was osiąść, a ma jakiś zawód, niech pracuje, by się wyżywić. Jeśli zaś nie ma żadnego zawodu, zadbajcie rozsądnie o to, by chrześcijanin nie żył wśród was w bezczynności. Gdyby zaś nie chciał tego czynić, znaczyłoby to, że kupczy Chrystusem. Strzeżcie się takich ludzi”; por. Longosz, Ksenodochium, s. 328. 
nia tzw. polecających listów pokoju (litterae commendatitiae et formatae ${ }^{46}$ ), wydawanych przez biskupów udającym się w podróż pątnikom i wiernym z prośbą o opiekę nad nimi i gościnne przyjęcie ${ }^{47}$, oraz potwierdzających, iż są w łączności ze swoim biskupem. Nie są one bynajmniej wytworem typowo chrześcijańskim, lecz zaczerpniętym z tradycji przedchrześcijańskiej ${ }^{48}$; z czasem chrześcijaństwo wypracowało ich pełną formę ${ }^{49}$. Przepisy kościelne (i to zarówno ustawodawstwo synodalne $e^{50}$, jak i soborowe) wymagały ich posiadania, zwracając przy tym uwagę na fakt, iż nie brakuje oszustów pragnących wykorzystać chrześcijańską gościnność i instytucje dobroczynne sub specie peregrinationis ${ }^{51}$. Ostrożność wynikała przede wszystkim z faktu, że pobyt $\mathrm{w}$ ksenodochium obejmował również opiekę duchową nad gośćmi i dopuszczenie ich do udziału w modłach i liturgii danej wspólnoty ${ }^{52}$. Listy polecające miały na celu przede wszystkim względy identyfikacji pielgrzyma lub wędrowca oraz umożliwiały mu opiekę ze strony instytucji kościelnych. Zawierały one również w swej treści prośbę o modlitwę i wstawiennictwo u świętych Apostołów. Początkowo chodziło oczywiście o wstawiennictwo rozumiane w sposób bardzo konkretny u samego rzymskiego biskupa, lub u innej ważnej osobistości w Wiecznym Mieście. Zalecały one również ochronę i pomoc ich właścicielowi - grzesznikowi udającemu się ad limina Apostolorum.

Wczytując się w poszczególne kanony reguł zakonnych możemy dowiedzieć się o szczegółach przyjmowania gości (hospites) w ksenodochiach klasz-

\footnotetext{
${ }^{46}$ Por. H. Leclercq, Litterae commendatitiae et formatae, DACL IX 2, 1571-1576.

${ }^{47}$ Wzmianki o nich odnajdujemy już w listach św. Pawła: ,Albo czy potrzebujemy, jak niektórzy

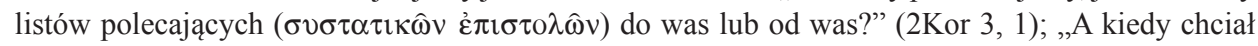
wyruszyć do Achai, bracia napisali list do uczniów z poleceniem, aby go przyjęli” (Dz 18, 27); por. też: Tt 3, 13; Ga 2, 4.

${ }^{48}$ Por. Forcellini, Lexicon totius latinitatis, III, s. 100-101, lub Prati 1865, 782 (Litterae).

${ }^{49}$ Por. Leclercq, Litterae commendatitiae, DACL IX 2, 1574-1576; przykłady formuł łacińskich zob. Formulae Marculfi II 49, MGH Leges V 32-112; zob. też: II 46 (Commendatias litteras ad episcopo noto); II 47 (Item conmendatias litteras ad abbate noto); II 48 (Supplecaturio pro eo qui in monasterio conversare desiderat); II 50 (Indecolum conmendatium ad viros inlustros laicos); II 51 (Indecolum ad homines potentes palatinus, maxime ad cognitos sibi) i inne.

${ }^{50}$ Por. Concilium Antiochenum (341) can. 7, Mansi II 1312 lub ed. P.P. Joannou I 2, 110, thum. A. Znosko: Kanony Kościoła Prawosławnego, t. 1, Warszawa 1978, 153: „Nikogo z obcych nie przyjmować bez kościelnego listu pokoju”; zob. też: Concilium Eliberitanum (305) can. 25, SCL 1 lub ŹMT 37, 53: "Każdemu kto przedłożyłby list polecający (litterae confessorias) należy dać świadectwo komunii z Kościołem z pominięciem imienia wyznawcy”; Concilium Laodicenum (325/381) can. 41-42; Concilium Sardicense (342/343) can. 7 i 8; Concilium Carthaginiense (419) can. $23,89,106$.

${ }^{51}$ Por. Concilium Nemausense 5, CCL 148, 50: „Additum etiam est, ut quia multi sub specie peregrinationis de ecclesiarum conlatione luxoriant, victura non omnibus detur".

${ }^{52}$ Por. Regula Benedicti 53, 8-9, SCh 182, 612, thum. benedyktyni tynieccy, PSP 26, 221: „Po powitaniu wypada zaprowadzić gości na modlitwę. [...] Trzeba przeczytać gościom ku ich zbudowaniu coś z Prawa Bożego"; zob. też Longosz, Ksenodochia, s. 329.
} 
tornych $^{53}$. Starożytni prawodawcy monastyczni akcentowali w nich przede wszystkim Chrystusowe przykazania miłości bliźniego, z którego wypływać miały takie, a nie inne zachowania wobec przybyłych, szukających schronienia i często pomocy różnego typu: medycznej, duchowej etc. Czynnikiem, który je łączył, była chęć niesienia wszelkiej pomocy wszystkim, którzy jej potrzebowali - w szczególności zaś tym, którzy podejmowali trud peregrinationis ad loca sancta.

Rzymska peregrinatio christiana w 2. poł. VI i na początku VII stulecia zmieniła nieco swą treść religijną. Podniesiono do dużej rangi ideę ,ut limina apostolorum Petri et Pauli visitarent"54. Oprócz kultu relikwii ex contactu, który przyjął się również wśród Germanów, zaczęły się pojawiać peregrynacje o charakterze ekspiacyjnym. Relikwie czczono już nie tylko na miejscu, ale przesyłano je niekiedy aż do miejsc bardzo odległych. Na Zachodzie - o czym powszechnie wiadomo - nieco dłużej pamiętano o rzymskim prawie zabraniającym naruszania grobu, uznając takie postępowanie za profanację ${ }^{55}$. Znacznie wolniej pokonywano tu opory przeciw ekshumacjom, przenoszeniu, czy parcelacji szczątków. W zasadzie aż do VII wieku w Rzymie dokonano niewielu, a do tego nietypowych, translacji.

„Nieobfitujące” w ciała świętych okolice, pomniejsze kościoły, a tym bardziej prywatne osoby, miewały trudności w zaopatrywaniu się nawet w drobne fragmenty upragnionych szczątków męczenników i świętych. Ubiegano się więc o relikwie wtórne - ex contactu - uzyskiwane przez kontakt z autentykiem, zwane rękojmią, czy dowodem miłości ze strony świętego - pignora sanctorum. Grzegorz Wielki ofiarował królowej Teodolindzie palestyńskie ampułki napełnione oliwą, pochodzącą z grobowców rzymskich męczenników (relikwie zanurzano w oliwie, która nabierać miała przez kontakt ze szczątkami świętego cudownych właściwości ${ }^{56}$. Najczęstszymi dewocjonaliami były: płótno (brandeum), olej z lampy płonącej przy sarkofagu, zebrany zeń mech czy pył, albo szata położona przy grobie, zwłaszcza przy konfesji św. Piotra w Rzymie (palliola). Pątnicy zabierali je ze sobą wierząc, iż zapewniają sobie tą drogą ze strony Chrystusa dalszą pomoc, błogosławieństwo i obronę przed złem bezpośrednio, bądź też pośrednio za pośrednictwem czczonego męczennika, którego miejsce kultu nawiedzali.

${ }^{53}$ Por. Pawłowska, Urbs Sacra, s. 241-246.

${ }^{54}$ Gregorius Turonensis, Historia septem dormientium 5, PL 71, 1115A: „Sequenti autem die, omnem peregrinationis suae seriem retexuerunt, voluntatemque suam in hoc esse dicens, ut limina apostolorum Petri et Pauli visitarent, ut et in Hierosolymis peregerent, sepulchrum Domini visitaturi, et crucem Domini adoraturi".

55 Edykt cesarza Teodozjusza z 386 r. powtarzał starożytny nakaz grzebania zmarłych poza miastem oraz zabraniał ich ekshumacji i przenoszenia (humatum corpus nemo ad alterum locum transferat), dzielenia ciał męczenników i handlu nimi (nemo martyrem distrahat, nemo mercetur), por. Cod. Theod. VIII 17. 7 (386 Febr. 26), ed. Mommsen, Berlin 1954, 463.

${ }^{56}$ Por. Jastrzębowska, Pielgrzymie dewocjonalia, s. 13-14. 
Rzym, podobnie zresztą jak i inne ośrodki chlubiące się relikwiami strzegł ich bardzo ${ }^{57}$. Gdy żona cesarza Maurycjusza (582-602) - Konstantyna poprosiła Grzegorza I (czerwiec 594) o głowę św. Pawła dla nowego kościoła w Konstantynopolu, otrzymała odpowiedź:

„[Rzymianie] dając relikwie świętych nie mają zwyczaju ani śmiałości dotykać się jakiejkolwiek części ich ciała"58.

Takie zachowanie narażało bowiem wiernych na niebezpieczeństwo. Wsparł on swą odmowę opowieściami m.in. o przypadkowym otwarciu grobu św. Wawrzyńca:

„Wszyscy tam pracujący mnisi i kościelni (mansionarii), którzy ciało tegoż męczennika widzieli, ale dotknąć się go nie odważyli, w ciągu dni dziesięciu zmarli, tak że nie został przy życiu żaden z tych, którzy widzieli jego ciało" $" 59$.

Grzegorz obiecał wysłać cesarzowej opiłki z Pawłowych kajdan ${ }^{60}$ oraz chustę $(\text { brandeum })^{61}$; polecił umieścić je w konsekrowanym kościele. Dla podniesienia rangi relikwii pod taką postacią dodał, że kiedyś, gdy Grecy powątpiewali w jej wartość Leon I, przeciął tkaninę nożycami, a z materiału popłynęła krew ${ }^{62}$.

Kiedy sami władcy nie mogli przybyć, mieli zwyczaj wysyłać swoich przedstawicieli, którzy w ich imieniu składali dowody pobożności domagając się w zamian relikwii ${ }^{63}$. Sam biskup Tours - Grzegorz (538/539-594) wysłał

${ }^{57}$ Por. J. Kracik, Relikwie, Kraków 2002, spec. 73-149.

${ }^{58}$ Gregorius Magnus, Epistula IV 30, CCL 140, 249, Czuj II 40-41; dalej czytamy: „W okolicach Rzymu bowiem, a raczej na całym Zachodzie, jest w ogóle rzeczą niedopuszczalną i świętokradzką, aby ktokolwiek chciał dotknąc ciał świętych".

${ }^{59}$ Tamże, CCL 140, 249, Czuj II 40.

${ }^{60}$ Por. tamże, CCL 140, 250, Czuj II 42: „O ile zdołam odpiłować - jakieś cząstki z łańcuchów, które św. Paweł Apostoł nosił na szyi i rękach, a przez które wiele się dzieje cudów wśród wiernych. Ponieważ bowiem wielu ludzi często przychodzi i prosi o cząstkę odpiłowaną z tychże kajdan i o błogosławieństwo, przeto stale jest obecny kapłan z piłą i dla niektórych proszących tak szybko odłącza się cząstka tych kajdan, że nie powstaje żadna zwłoka. Na prośby zaś niektórych długo wodzi się piłą po łańcuchach, a jednak niczego nie można z nich uzyskać”.

${ }^{61}$ Por. tamże, CCL 140, 249, Czuj II 41: „Posyła się w puszce jedynie chusty i przykłada do uwielbionych ciał świętych. Zabrane stamtąd składa się z należną czcią w kościele, który ma być poświęcony, i tak wielkie tamże dzięki nim dzieją się cuda, jak gdyby specjalnie złożone tam były ich ciała".

${ }^{62}$ Por. tamże.

${ }^{63}$ Rzymska epigrafika katakumbowa schyłku starożytności chrześcijańskiej nie może być w żadnym wypadku podstawą do szczegółowych analiz statystycznych. Stosunkowo liczne graffiti naścienne z tego okresu świadczą o obecności tu chrześcijan z różnych, często bardzo odległych stron świata chrześcijańskiego. Szczegółowa typologia zob. Pawłowska, Urbs Sacra, s. 304-306 i 309-315, podana za: C. Carletti, „Viatores ad martyres”. Testimonianze scritte altomedievali nelle catacombe romane, w: Epigrafia medievale greca e latina. Ideologia e funzione (Erice $12-18$ sett. 1991), a cura di G. Cavallo - C. Mango, Spoleto 1995, 208-209 i 212-216. 
w 590 r. swego diakona Agiulfusa do Wiecznego Miasta, a nawet jeszcze dalej na Wschód, po relikwie lub ich namiastki. Diakon pokonał wszelkie przeciwności, które pojawiły się podczas jego podróży (przeprawa przez morze, zaraza - dżuma, która zdziesiątkowała Rzym w 589 roku), asystował przy śmierci Pelagiusza II (590), a także przy wyborze Grzegorza I Wielkiego ${ }^{64}$. Powrócił do Tours, mijając po drodze Lyon, z relikwiami świętych; a więc z całym dziedzictwem potrzebnym do konsekracji nowych kościołów ${ }^{65}$. W tym samym źródle odnajdziemy też wzmiankę o podróży diakona andegaweńskiego - Magnebodusa (Maimbeuf), wysłanego z podobną misją do Wiecznego Miasta. Takie „delegacje”, jak łatwo się można domyślić, przybywały z całego Zachodu, a pośrednim dowodem na to jest fakt tak wielkiego rozproszenia relikwii Apostołów i męczenników lub ich namiastek po niemalże całej Europie ${ }^{66}$. Inna wzmianka informuje nas, że cesarz Justynian (527-565) zwrócił się do biskupa Rzymu Hormisdasa o przysłanie mu relikwii - choćby małego fragmentu rusztu, na którym był dręczony św. Wawrzyniec (craticula beati Laurentii martyris) ad secundam cataractam $^{67}$. Podobnego typu podróż ad beati apostoli tumulum odbył galijski biskup Aravatius, celem zapewnienia sobie orędownictwa mocy apostolskiej, i by łatwiej otrzymał łaski, o które pokornie prosił ${ }^{68}$. Obok intensywnej modlitwy u grobu św. Piotra, umartwiał się poprzez:

${ }^{64}$ Por. W.J. La Due, Na tronie św. Piotra. Historia papiestwa, thum. M. Mieciecielica Ł. Tobaka, Wrocław 2004, 81-87.

${ }^{65}$ Por. Gregorius Turonensis, Historia Francorum X 1, MGH Script. Rer. Merov. I 406-409: „Anno igitur quinto decimo Childeberthi regis diaconus noster ab urbe Roma sanctorum cum pigneribus veniens, sic retulit, quod anno superiore, mense nono tanta inundatio Tiberis fluvius Romam urbem obtexerit"; por. thum. K. Liman - T. Richter: Grzegorz z Tours, Historia Franków, Kraków - Tyniec 2002, 417; zob. tenże, Vitae Patrum VIII 6; MGH Script. Rer. Merov. I 696: „Agiulfus quoque diaconus noster a Roma veniens, beata nobis sanctorum pignora deferebat"; por. także tenże, De gloria martyrum 82.

${ }^{66}$ Por. Historia Francorum VI 6, MGH Script. Rer. Merov. I 252: „Quaerebam Petrum, quaerebam Paulum Laurentiumque vel reliquas, qui Romam proprio cruore inlustratum: hic omnes repperi, hic cunctos inveni", tłum. Liman - Richter, s. 265.

${ }^{67}$ Por. Suggestio legatorum ad Hormisdam papam, PL 63, 474: „Filius vester magnificus vir Iustinianus, res convenientes fidei suae faciens, basilicam sanctorum Apostolorum, in qua desiderat et beati Laurentii martyris reliquias esse, constituit, sperat per parvitatem nostram, ut praedictorum sanctorum reliquias celeriter concedatis [...]. Unde si et beatitudini vestrae videretur, sanctuaria beatorum apostolorum Petri et Pauli, secundum morem, ei largiri praecipite; et si fieri potest, ad secundam cataractam ipsa santuaria deponere, vestrum est deliberare. Petit et de catenis sanctorum apostolorum, si possibile est, et de craticula beati Lauentii martyris".

${ }^{68}$ Por. Historia Francorum II 5, MGH Script. Rer. Merov. I 66: „Igitur rumor erat, Chunos in Galliis velle prorumpere. Erat autem tunc temporis apud Tungrus oppidum Araxatius, eximiae sanctitatis episcopus [Aravatius - przyp. aut.] [...] precabatur ne unquam gentem hanc in Galliis venire permitterit. Sentiens per spiritum, pro delictis populi sibi hoc non fuisse concessum, consilium habuit expetendi Urbem romanam, scilicet ut adiunctam sibi apostolicae virtutis patrocinia, quae humiliter ad Dei misericordiam flagitabat mereretur facilius obtinere. Accedens ergo ad beati apostoli tumulum, depraecabatur auxilium bonitate eius, in multa abstinentia, maxime inaedia se consumens, 
„Częstą wstrzemięźliwość i ustawiczny post [...], że przez dwa lub trzy dni pozostawał bez jakiegokolwiek pokarmu i napoju" ${ }^{\prime \prime}$.

W dziele Grzegorza z Tours czytamy też o tym, jak wielką wiarę przywiązywano do modlitwy przy grobach świętych męczenników w Rzymie. Pewien mieszkaniec Angers wskutek silnej gorączki stracił słuch i mowę. Na wieść, że do Wiecznego Miasta po relikwie ,świętych Apostołów lub innych patronów tego miasta" udawał się jeden z diakonów, krewni głuchoniemego zaczęli usilnie prosić, by raczył zabrać go w podróż. Wierzyli oni bowiem bardzo mocno, że gdy tylko nawiedzi groby świętych Apostołów, odnajdzie tam ratunek ${ }^{70}$.

Często, sami biskupi Rzymu sprzyjali nadawaniu bardziej duchowego charakteru podróżom do Rzymu - ad limina apostolorum, peregrinatio pro Ecclesia. Pouczenia papieskie wskazywały na większe znaczenie duchowej odnowy pątników od znaczenia samych relikwii, tzw. brandea, tj. tkanin, które stawały się relikwiami ex contactu ${ }^{71}$. Jednak, jak się wydaje, same relikwie $\mathrm{w}$ sensie stricte materialnym, miały bardzo wielkie znaczenie dla młodych, chrześcijańskich narodów Europy, która już na przełomie VI i VII wieku stawała się Orbis Christianus ${ }^{72}$. Począwszy od Damazego biskupi rzymscy wzywali biskupów sąsiednich prowincji na uroczystości rocznicy swej elekcji i zwoływali synody w bazylice watykańskiej. Grzegorz Wielki w jednym ze swych listów wspomina z szacunkiem i stawia za wzór Kasjusza, biskupa Narni († 558), który nigdy nie opuścił takich zgromadzeń - ale zwraca też uwagę biskupowi Rotomageńskiemu, że je zaniedbuje ${ }^{73}$.

Również w innych listach nie szczędzi Grzegorz słów dezaprobaty dla biskupów, którzy próbują się od tego „obowiązku” uchyliç ${ }^{74}$, albo też zaprasza

ita ut bidui triduique sine ullo cibo potuque maneret, nec esset intervallum aliquod in quo ab oratione cessaret", thum. Liman - Richter, s. 101-102.

${ }^{69}$ Tamże II 5, MGH Script. Rer. Merov. I 66, tłum. Liman - Richter, s. 101.

${ }^{70}$ Por. tamże VI 6, MGH Script. Rer. Merov. I 251: „Igitur diaconus ex provintia illa Romam directus est, ut beatorum apostolorum pignora vel reliquorum sanctorum qui urbem illam muniunt, exhiberet", thum. Liman - Richter, s. 264.

${ }^{71}$ Por. H. Leclercq, Brandea, DACL II 1132-1137.

${ }^{72}$ Sformułowanie za: G. Otranto, Il pellegrinaggio nel cristiantessimo antico, VetCh 36 (1999) 242.

${ }^{73}$ J. Gaume powołuje się (Historya katakumb, czyli Rzym podziemny, Warszawa 1854, s. 51, nota 1) na poparcie tego na dwa Grzegorzowe listy - IX 1 i IX 20, których jednak nie ma w tym miejscu w wydaniu CCL, por. Epistula IX 1: „Qui vero labor, aut quae difficultas prae alias dissuasit vobis per tantum spatii beatum Petrum negligere, ubi et ab ipsius mundi finibus, etiam gentes noviter ad finem conversae student omnes tam mulieres quam viri ad eum venire"; zaś do innego biskupa imieniem Lanfranca pisze (Epistula IX 20): „Non enim labor aut difficultas itineris te sufficienter excusat, cum satis notum sit multom longe remotas, licet corpore invalidos, et infirmos ut a lectulis vix valentes surgere, tamen beati Petri amore flagrantes, ad eius limina vehiculis properari"; o takim postepowaniu tego biskupa zob. Gregorius Magnus, Dialogi III 6 i IV 6; In Evangelia hom. 2, 37; R. Van Doren, Cassius, evêque de Narni, DHGE XI 1409.

${ }^{74}$ Por. Epistula V 35, CCL 140, 302, Czuj II 93-94 (maj 595): „Otrzymałem miłe pismo Waszej Świątobliwości, w którym daliście mi zadośćuczynienie, tak że nie powinienem gniewać się, iż nie 
biskupów do przybycia ad limina sancti Petri apostolorum principis i odprawienia uroczystych nabożeństw oraz mszy w towarzystwie biskupa Rzymu ${ }^{75}$, na wspólne rozmowy ${ }^{76}$ lub na dysputy teologiczne w trakcie zwoływanych synodó $\mathrm{w}^{77}$. Co ciekawe, sformułowanie: ad beati apostolorum principis limina stało się synonimem nie tylko samych miejsc kultu Apostołów, ale również Rzymu, jako stolicy Piotrowej ${ }^{78}$. Zrodziła się wiara w opiekę Apostołów,

przybyliście do progów błogosławionego Piotra, Księcia Apostołów (ad beati Petri apostolorum principis limina non venistis)”; zob. Pawłowska, Urbs sacra, s. 300-303.

${ }^{75}$ Por. Epistula I 27 (luty 591), CCL 140, 35, Czuj I 50: „Prócz tego donoszę, iż zwróciłem się do pobożnych panów z usilną prośbą, aby zezwolili świątobliwemu mężowi, dostojnemu monarsze Anastazjuszowi [usunięty ze stolicy patriarszej w Antiochii - przyp. aut.], obdarzonemu przywilejem paliusza, przybyć do progów błogosławionego Piotra, Księcia Apostołów i odprawić ze mną uroczyste msze (ad beati Petri apostolorum principis limina me cum celebraturum sollemnia missarum transmittere debuisset)".

${ }^{76}$ Por. Epistula I 7 (590), CCL 140, 9-10, Czuj I 11: [Grzegorz do biskupa Anastazjusza, którego w 570 r. cesarz Justyn II usunął go ze stolicy, a uznał jego następcą Grzegorza] „Prócz tego donoszę, że jak tylko mogłem, prosiłem najjaśniejszych panów, aby wam - po przywróceniu zaszczytu - pozwolili przybyć do progów św. Piotra - Księcia Apostołów (ad sancti Petri apostolorum principis limina venire). Obyście tu mogli żyć ze mną, jak długo Bóg pozwoli, abyśmy rozmową o wiecznej ojczyźnie mogli sobie wzajemnie uprzyjemnić ciężkie nasze pielgrzymowanie, o ile tylko zasłużę na oglądanie was”; zob. też: Epistula IX 15 (październik 598), CCL 140A, 576, Czuj III, 67 [Grzegorz pozdrawia znakomitego męża z Katanii i zaprasza go do Rzymu\}: „A chociaż ja, grzesznik, bardzo jestem zajęty, to jednak jeślibyś zachciał przybyć do progów błogosławionego Piotra Apostoła (tamen si ad beati Petri apostoli limina venire volueris), możesz mieć we mnie rzetelnego pomocnika w świętych rozmowach".

${ }^{77}$ Por. Epistula I 16 (styczeń 591), CCL 140, 16, Czuj I 18 [Grzegorz do Sewera, biskupa Akwilei]: „Przeto w obecności oddawcy tego pisma, zgodnie z rozkazem nader chrześcijańskiego i najjaśniejszego władcy chcemy, byś ze swoimi zwolennikami przybył do progów błogosławionego Piotra Apostoła (ad beati Petri apostoli limina cum tuis sequacibus venire), aby na zgromadzonym z woli Bożej synodzie [590 r. - przyp. aut.] odbył się sąd nad waszym powątpiewaniem".

${ }^{78}$ Por. m.in. Epistula IX 179 (lipiec 599), CCL 140A, 737, Czuj III 212 [Grzegorz I ubolewa, że opat Klaudiusz nie przybył wraz z biskupem Sewerem]: „Spodziewałem się, że razem z przewielebnym mężem, biskupem Sewerem, przybędzie do progów błogosławionego Piotra Apostoła (ad beati Petri apostoli limina pariter venire) także Wasza Miłość, ponieważ jak mi doniesiono i bardzo się tą wieścią cieszyłem”; Epistula XI 55 (lipiec 601), CCL 140A, 959, Czuj IV 119-120 [Grzegorz I do biskupa Tessaloniki Euzebiusza]: „Oddawca niniejszego listu, Teodor, lektor waszego kościoła, przybywszy do progów świętych Apostołów (ad sanctorum apostolorum limina veniens), a nie znając nikogo jako człowiek nowy, przywiezione rzeczy i papiery odniósł do mnicha Andrzeja, zamkniętego w celi u św. Pawła, dawnego swego znajomego i w poczciwości swej zostawił tam w przekonaniu, że zapatrywania jego - jak i my przedtem sądziliśmy - odpowiadają habitowi”; Epistula XI 59, CCL 140A, 966, Czuj IV 138: „A co do tego, że jak mówicie, spieszycie do progów błogosławionego Piotra, Księcia Apostołów (ad beati apostolorum principis limina festinare vos dicitis), bardzo sobie tego życzę i oczekując tego gorąco pragnę zobaczyć was w Jego kościele złączone godnymi zasługami, abyście i wy miały ze mnie odrobinę pociechy, i ja niemałą radość z waszej obecności”; Epistula VIII 22 (maj 598), CCL 140A, 541, Czuj III 33: „Przypominam sobie, że już dawno pisałem do Waszej Dostojności i często nalegałem, byście się postarali powrócić do 
zwłaszcza św. Piotra nad Rzymem, nękanym przez różne nieszczęścia i kataklizmy ${ }^{79}$ :

„Jeśli zaś obawiacie się mieczów Italii i wojen, powinniście skwapliwie przyjąć do wiadomości, jak wielka jest opieka błogosławionego Piotra, Księcia Apostołów (beati Petri apostolorum principis in hac urbe protectio est), $\mathrm{w}$ tutejszym mieście, gdzie bez mnogiej ludności i bez pomocy przez tyle lat za Bożą pomocą żyjemy wśród mieczów nie doznawszy obrażeń" ${ }^{\circ 0}$.

W ciągu kolejnych dziesięcioleci najazdy barbarzyńców dokonały takich zniszczeń, że ubożejące papiestwo, nie mogąc - z braku środków - ciągle odrestaurowywać dewastowanych sanktuariów, postanowiło przenieść w obręb Miasta relikwie męczenników, by je uchronić przed profanacją i całkowitą zagładą. Na mocy dekretów papieskich katakumby stały się „kopalniami” świętych relikwii, które wywożono - już teraz legalnie - masowo z Rzymu, a następnie pieczołowicie wystawiano je w złotych relikwiarzach w kaplicach i kościołach całej Europy ${ }^{81}$. W ten sposób rzymskie katakumby „straciły [...] swą główną siłę, która przyciągała ku sobie rzesze pobożnych pątników" "82, a pamięć o większości z nich zaczęła się coraz bardziej zacierać. Zwyczaj chowania zmarłych w pobliżu grobów męczenników zastąpiono grzebaniem ich na cmentarzach przykościelnych, już na terenie średniowiecznego Rzymu.

\section{PEREGRINATIO CHRISTIANA NACH ROM IN ZEITEN VON GREGOR DES GROSSEN}

\section{(Zusammenfassung)}

Zum Ende der christlichen Antike, also in Zeiten von Gregor des Grossen ist die Formulierung: ad beati apostolorum principis limina nicht nur zum Synonym für Kultstätten von Apostel, aber auch von Rom als Stuhl Petri geworden. Zu dieser Zeit wurde der Glaube an Schutz der Apostel, vor allem des Heiligen Petrus über Rom, das damals von verschiedenem Unheil und Kataklysmen geplagt wurde, geboren. Selbst die Bischöfe von Rom begünstigten die Reisen nach Rom und verliehen diesen einen geistlichen Charakter - ad limina apostolorum, peregrinatio pro Ecclesia.

Die Errichtung von Pilgervierteln in der Nähe von römischen loca sancta, die für Leute gedacht waren, die eine Wallfahrt unternahmen, wurde zur „Ehrensache”

progów błogosławionego Piotra, Księcia Apostołów (ut beati Petri apostolorum principis limina revidere festinet)".

${ }^{79}$ Por. Epistula IX 240, CCL 140A, 824, Czuj III 288: „Albowiem miasto Rzym za nasze grzechy nękają różne nieszczęścia, tak że nie ma tu nawet ludzi zdatnych do strzeżenia murów".

${ }^{80}$ Epistula VIII 22 (maj 598), CCL 140A, 542, Czuj III 34.

${ }^{81}$ Por. M. Cecchelli, Effetti delle grandi translazioni nelle basiliche Romane, w: Quaeritur inventus colitur, s. 109-121.

${ }^{82}$ J. Bilczewski, Archeologia chrześcijańskia wobec historii Kościoła i dogmatu, Kraków 1890, 8. 
für Bischöfe und weltliche Würdenträger, da es als deutliches Zeichen der Umsetzung der von Christi anbefohlenen christlichen Tugenden wie: Gastlichkeit - hospitalitas und Dienstbarkeit dem Nächsten galt. Diese „Nebeneinrichtungen” für Einreisende in die Kultstätten garantierten Ihnen einige Bequemlichkeiten, den Seelsorgern dagegen verhalfen im Katechese und „Aufsicht” über die Pilger. 
